\title{
Retrospective Analysis of Arthroscopic Cam Decompression. Is Hip Joint Still Preserved Although at Learning Curve?
}

\section{Artroskopik Cam Dekompresyonun Geriye Dönük Analizi. Öğrenme Eğrisinde Olmasına Rağmen Kalça Eklemi hala Korunuyor mu?}

\section{Cihangir Türemiş ${ }^{\oplus}$, Onur Hapa ${ }^{\oplus}$}

Department of Orthopedic Surgery, Dokuz Eylül University, İzmir

Received: 05.02.2021 / Accepted: 02.03.2021 / Published Online: 31.03.2021

Cite as: Türemiş C, Hapa O. Retrospective analysis of arthroscopic cam decompression. Is hip joint still preserved although at learning curve?. Turk J Hip Surg 2021;1(1):32-6.

\section{ABSTRACT}

Hip arthroscopy is an effective treatment for femoroacetabular impingement (FAI). The purpose of the present study was to report retrospectively the patients self-reported outcomes, and hip survival rates within a mean follow-up of five years.

Retrospectively collected data on 25 patients with FAl within a minimum follow-up of 42 months (mean 60 months) treated with hip arthroscopy and labrum repair were analyzed. The primary outcome measures were the Hip Outcome Score (HOS) Activities of Daily Living (ADL) subscale, HOS-Sport subscale, Visual analog scale (VAS) for pain. Patient satisfaction was rated. Measurement of joint spaces and osteoarthritis (Tonnis) grading were done preoperatively and at the last follow-up visit.

Pre- and postoperative mean alpha angles were $67 \pm 4$ degrees $46 \pm 3$ degrees, respectively. Minimal clinically important difference (MCID) was achieved for HOSADL in $76 \%$, and for HOSSS in $56 \%$ of the patients, while all patients achieved MCID for VAS pain scores. Mean satisfaction level was $7.5 \pm 1.8$ Mean preoperative Tonnis stage of the patients was $0.9 \pm 0.9$ which increased to $1.1 \pm 0.8$ ( $p: 0.046)$. Mean preoperative lateral joint space was $4.8 \pm 1$ which decreased to $4.5 \pm 1 p<0.001$. Mean middle joint space also decreased from $4.5 \pm 0.9$ to $4.3 \pm 0.7$ ( $p: 0.04)$. However this decrease was not statistically significant at joint space measured at foveal level ( $p>0.05)$ ( $5 \pm 0.8$ vs $4.9 \pm 0.7)$.

Mid-term results show that after cam decompression, it is possible to say that hip joint is at least preserved and progression of hip osteoarthritis seems to be delayed. Patient functional results, and pain scores are generally improved in accordance with the literature data.

Keywords: hip arthroscopy, femoro-acetabular impingement, osteoarthritis

öz

Kalça artroskopisi, femoroasetabular sıkışma (FAS) için etkili bir tedavidir. Bu çalışmanın amacı, ortalama beş yıllık takip süresinde geriye dönük olarak hastaların bildirdiği sonuçları ve kalça sağkalımını rapor etmekti.

Kalça artroskopisi ve labrum tamiri ile tedavi edilen minimum 42 aylık (ortalama 60 ay) takipte FAS'ı 25 hastadan geriye dönük olarak toplanan veriler analiz edildi.

Birincil sonuç ölçütleri, Kalça sonuç skoru (HOS) günlük yaşam aktiviteleri (ADL), HOS-Spor ölçekleri ve ağrı için görsel analog ölçeği (VAS) idi. Hasta memnuniyeti derecelendirildi. Eklem boşluklarının ölçümü ve osteoartrit (Tönis) derecelendirilmesi ameliyat öncesi ve en son takipte yapıldı.

Ameliyat öncesi ve sonrası ortalama alfa açıları $67 \pm 4$ derece ve $46 \pm 3$ dereceydi. Hastaların $76 \%$ 'sında HOSADL için minimal klinik önemli fark (MCID) elde

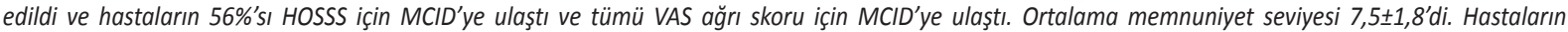

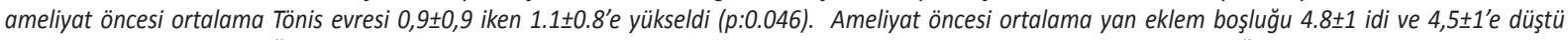

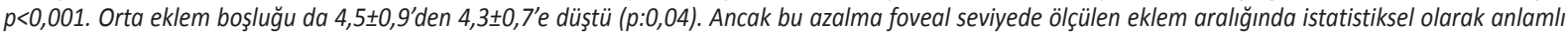
değildi $(p>0,05)(5 \pm 0,8$ vs $4,9 \pm 0,7)$.

Ara dönem sonuçları, cam dekompresyonundan sonra kalça ekleminin en azından korunduğunu ve kalça osteoartritinin ilerlemesinin geciktiğini söylemenin mümkün olduğunu göstermektedir. Hastanın fonksiyonel sonuçları ve ağrı skorları genellikle literatürle uyumlu olarak iyileşir.

Anahtar sözcükler: kalça artroskopisi, femoro-asetabular sıkısma, osteoartrit

Corresponding Author:

cihangirturemis@gmail.com
C. Türemiş 0000-0002-5794-6652 O. Hapa 0000-0001-8154-658X 


\section{INTRODUCTION}

Symptomatic femoroacetabular impingement (FAI) occurs secondary to abnormal contact between the proximal femur and acetabulum due to cam, pincer or mixed morphology. This contact later may lead to symptomatic labrum tear, chondral damage and finally the osteoarthritis (OA) ${ }^{(1)}$. Most studies have reported that although patients with FAI benefit from physical therapy, surgical management with hip arthroscopy is more beneficial for patients. However whether this surgery prevents or delays osteoarthritis is still not certain (2). Whereas most recently, level of evidence increased indicating that cam morphology of femoral head (asphericity) leads to development of hip osteoarthritis due to acetabular chondral damage (3-7). Supporting this, Domb et al. ${ }^{(7)}$ also reported that in patients treated with hip arthroscopy and optimal resection, cam deformity (postoperative $\alpha$ angle $<55^{\circ}$ ) had lower incidence of conversion to total hip arthroplasty than incomplete resection (postoperative $\alpha>55^{\circ}$ ). A recent in vitro study also confirmed that accurate cam resection restored normal peak joint contact stresses ${ }^{(8)}$.

Despite advances in surgical techniques, instruments and knowledge, hip arthroscopy is still a demanding procedure and has steep learning curve ${ }^{(9-11)}$. Recent review reported that 30 cases is most commonly used cut-off number for learning curve to increase the chance of successful outcome and/or decrease the number of complications ${ }^{(12-14)}$.

Purpose of the present study was to report the results of first cases of a single surgeon and to see whether patients had decreased joint space or increased degree of the osteoarthritis at the latest follow-up. Hypothesis was that restoration of alpha angle or correction of cam deformity would prevent or delay the development of hip osteoarthritis at symptomatic FAl patients at midterm although surgery was performed during learning curve of the surgeon.

\section{Patients and methods}

After local institutional ethics committee approval, retrospective data on all patients undergoing hip arthroscopy between 2013-2016 for the treatment of FAl by single surgeon $(\mathrm{OH}$, first cases) was included in the study. Patients were excluded if they had osteonecrosis of the femoral head, Perthes disease sequelae, history of hip trauma, and dysplasia.

All patients had positive physical examination and magnetic resonance imaging (MRI) findings to confirm the diagnosis of FAI and labrum tear. Cam type deformity was defined as $\alpha$ angle $>60^{\circ}$ at pre-operative Dunn X-ray ${ }^{(15)}$ and a pincer deformity was defined as lateral centeredge angle (LCEA) $>40^{\circ}$ and/or cross-over sign ${ }^{(16,17)}$ at pelvis $X$-rays. Tönnis grading was performed ${ }^{(18)}$ and the joint space was measured at 3 locations: the lateral edge, middle of the sourcil, and above the level of the fovea at neutral pelvic $X$ ray (Figure 1 ) in the supine position $^{(19)}$.

Arthroscopy was performed with the patient in supine position on a traction table using anterolateral, anterior, mid-anterior portals. After inter-portal capsulotomy, diagnostic arthroscopy was performed, the labrum tear was identified, pincer lesion was then excised. All patients received labrum repair. Number of anchors (Gryphon, Depuy Synthes, USA) used changed between 1-3 (mean 1.6 anchors). Afterward cam lesions were

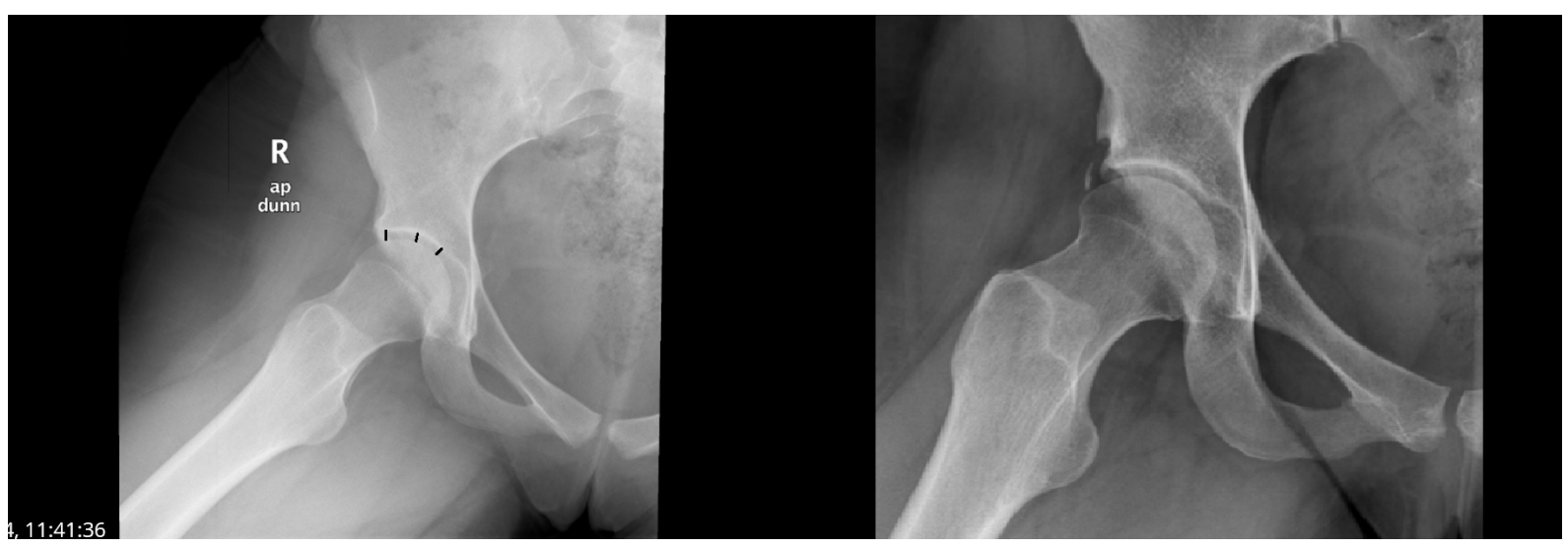

Fig 1. Joint space measurements (Dunn X-rays of the patients obtained preoperatively, and at postoperative 6 years ) 
Table I. Patients self- reported outcomes and radiographic measurements ( 0 degrees, mean $\pm S D$ 'standard deviation', Cl; \%95 confidence interval)

\begin{tabular}{|l|l|l|l|}
\hline 31 hips $($ mean \pm SD $)[C I]$ & preoperative & Last postoperative visit & $p$-value \\
\hline Dunn $\alpha^{0}$ & $67 \pm 4[65-69]$ & $46 \pm 3[45-47]$ & $<0.001$ \\
\hline LCEA $^{0}$ & $42 \pm 8[39-45]$ & $31 \pm 2[30-32]$ & $<0,001$ \\
\hline Head-neck distance(mm) & $4 \pm 0.8[4-5]$ & $7 \pm 2[6-7]$ & $<0.001$ \\
\hline VAS & $9 \pm 0.7[8-9]$ & $2 \pm 1[2-3]$ & $<0.001$ \\
\hline HOS $_{\text {ADL }}$ & $63 \pm 14[57-68]$ & $86 \pm 15[81-92]$ & $<0.001$ \\
\hline HOS $_{\text {SS }}$ & $51 \pm 17[45-57]$ & $79 \pm 18[73-86]$ & $<0.001$ \\
\hline
\end{tabular}

Dunn $\alpha$ : Dunn alpha angle (degrees); LCEA, lateral center -edge angle; VAS: Visual Analogue Scale; HOS. Hip Outcome Score; ADL: Activities of Daily Living

excised and dynamic plus fluoroscopic examination was done to confirm adequate resection of impingement. Joint capsule was left open at all cases. Immediately patient started to practice passive hip range of motion exercises with $\% 20$ of body weight bearing using two crutches for three weeks postoperatively. Then patient started active exercises and weight bearing as tolerated.

Patient-reported outcome measures were collected retrospectively from each patient at the latest followup visit (mean 60 months '42-79months').

The primary outcome measure was the Hip Outcome Score (HOS) Activities of Daily Living (ADL) subscale, HOS-Sport subscale, Visual analog scale (VAS) for pain (20). Patient satisfaction was rated on a 10-point scale, with 1 indicating extremely unsatisfied and 10 indicating very satisfied ${ }^{(21,22)}$

\section{Statistical analysis}

Data analysis was performed using SPSS for Windows, version 22 (IBM, SPSS statistics). A value of $p<0.05$ was considered as statistically significant. Wilcoxon signed -rank test was used to compare variables obtained preoperatively and at the last follow-up visit.

\section{RESULTS}

Thirty-one hips of 25 patients ( 6 bilateral) were analyzed in the study. Average age of the patients (6 women, and 19 men) was 32 (19-47) years. Average follow-up period was 60 months (42-79months).

Preoperative and postoperative head-neck distance (mm), LCEA (degrees), Dunn $\alpha$ angles (degrees) are given in Table I which all changed significantly at early postoperative period $(p<0.05)$.
Mean preoperative Tönnis stage of the patients was $0.9 \pm 0.9$ [0.6-1.3] (mean \pm std [Cl 'confidence interval']) which increased to $1.1 \pm 0.8$ [0.7-1.4] (p:0.046). Mean preoperative lateral joint space was $4.8 \pm 1$ [4.4-5.3] which decreased to $4.5 \pm 1[4.1-4.9] p<0.001$. Mean middle joint space also decreased from $4.5 \pm 0.9[4.2$ $4.9]$ to $4.3 \pm 0.7[4-4.6]$ ( $p: 0.04)$. However, this decrease was not statistically significant at joint space measured at foveal level $(p>0.05)(5 \pm 0.8[4.7-5.3]$ vs $4.9 \pm 0.7[4.6$ 5.2]. Mean satisfaction level was $7.5 \pm 1.8[6.8-8.2]$ at the last follow-up visit.

Minimal clinically important difference (MCID) was achieved for HOSADL in $76 \%$, and for HOSSS in $56 \%$ of the patients, while all patients achieved MCID for VAS pain scores. Mean satisfaction level was 7.5 $\pm 1.8^{(23)}$.

\section{DISCUSSION}

Main finding of the present study was decrease of joint space measurement was approximately $0.3 \mathrm{~mm}$ at a mean follow-up of five years after cam decompression which probably not clinically significant. Thus it is possible to say that hip joint is at least preserved and progression of hip osteoarthritis is delayed.

Minimal clinically important difference is defined as the threshold value for smallest change in the outcome score resulting in a perceived improvement $(23,24)$. Studies calculated new MCID values for their study or they used the previously mentioned values. At the present study upper limits of MCID values for HOS described at the literature, were chosen ${ }^{(23)}$. Beck et al (25) followed up their adolescent patients (13-21 years of age) for a minimum 5 years, and reported that $\% 88$ of their patients achieved MCID for HOS. Lower values were reported at the present study due to higher age group and/or probably due to choosing the upper limit for MCID values. 
At another study with 45 patients (mean age of 34 years) Lee et al ${ }^{(26)}$. reported similar improvement at HOSADL (from 58 to 85) and HOSSS (from 51 to 82) after an average follow-up period of 7 years. Patient satisfaction was 7.6 of $10^{(26)}$.

Menge et al ${ }^{222}$. reported comparable degree of improvement for HOSADL (25 points) while higher magnitude of improvement for HOSSS (40 points) without any difference between treatment modalities used for the repair of the labrum (debridement or repair) in their 154 patients with an average age of 40 years. Higher rate of conversion to total hip arthroplasty was seen in patients with $\leq 2 \mathrm{~mm}$ joint space ${ }^{(22)}$. At the present study although some degree of joint space decrease was observed, neither preoperatively nor postoperatively critical joint space of $2 \mathrm{~mm}$ was seen at any patients. Whether this decrease of joint space at lateral and middle parts is clinically relevant, is the subject of future studies.

Our study has some limitations. First, this was a retrospective study with limited data. Second, the degree of chondral damage or labrum tear was not reported and there was not a control group for comparison. Results are those of a single surgeon at the learning curve that may limit generalization. It is reported that after learning curve is completed, complication rate, surgery time, re-operation rates are decreased. However the evidence also indicates that surgeons may still have successful outcomes when performing hip arthroscopy earlier in their careers ${ }^{(27,28)}$.

Lastly, joint space measurements were made at supine pelvic radiographs that may limit validity of the results however a more recent study has reported that standing and supine pelvic radiographs were not significantly different and both may be used to assess width of the joint space ${ }^{(29)}$.

This midterm results show that that after cam decompression, it is possible to say that hip joint is at least preserved and progression of hip osteoarthritis seems to be delayed. Patient functional results, pain scores were generally improved in line with the literature. However future prospective studies are still needed to further delineate the efficacy of this procedure to stop or delay progression of hip osteoarthritis.
Ethics Committee Approval: 2020-02

Conflict of Interest: No.

Funding: There is no funding.

Informed Consent: Yes.

\section{REFERENCES}

1. Ganz R, Parvizi J, Beck M, et al. Femoroacetabular impingement: a cause for osteoarthritis of the hip. Clin Orthop Relat Res 2003;417:112-120.

2. Gao I, Safran MR. Nonsurgical versus surgical management of femoroacetabular impingement: what does the current best evidence tell us. J Am Acad Orthop Surg. 2020 Dec 21. doi: 10.5435/JAAOS-D-20-00571

3. Hoch A, Schenk P, Jentzsch T et al. FAl morphology increases the risk for osteoarthritis in young people with a minimum follow-up of 25 years. Arch Orthop Trauma Surg 2020 Jun 29. doi: 10.1007/s00402-020-03522-3.

4. Kemp JL, $\emptyset$ sterås N, Mathiessen A. Relationship between cam morphology, hip symptoms, and hip osteoarthritis: the Musculoskeletal pain in Ullersaker STudy (MUST) cohort. Hip Int 2020 Jul 23;1120700020943853. doi: $10.1177 / 1120700020943853$.

5. Wylie JD, Kim YJ. The natural history of femoroacetabular impingement. J Pediatr Orthop. 2019 Jul;39(Issue 6, Supplement 1 Suppl 1):28-32 doi:10.1097/BPO.0000000000001385

6. Nelson AE, Stiller JL, Shi XA et al. Measures of hip morphology are related to development of worsening radiographic hip osteoarthritis over 6 to 13 year follow-up: the Johnston County Osteoarthritis Project. Osteoarthritis Cartilage. 2016 Mar;24(3):443-50. doi: $10.1016 /$ j.joca.2015.10.00

7. Domb BG, Annin S, Chen JW et al. Optimal treatment of cam morphology may change the natural history of femoroacetabular impingement. Am J Sports Med. 2020 Oct;48(12):2887-2896. https://doi.org/10.1177/0363546520949541

8. Van Houcke J, Khanduja V, Audenaert EA Accurate arthroscopic cam resection normalizes contact stresses in patients with femoroacetabular impingement. Am J Sports Med. 2021 Jan;49(1):42-48. doi: 10.1177/0363546520974378

9. Smith KM, Duplantier NL, Crump KH, et al. Fluoroscopy learning curve in hip arthroscopydA single surgeon's experience. Arthroscopy 2017;33:1804-1809. https://doi.org/10.1016/j.arthro.2017.03.026

10. Hoppe DJ, de Sa D, Simunovic N, et al. The learning curve for hip arthroscopy: A systematic review. Arthroscopy 2014;30:389-397. https://doi.org/10.1016/j.arthro.2013.11.012

11. Mehta N, Chamberlin P, Marx RG, et al. Defining the learning curve for hip arthroscopy: A threshold analysis of the volumeoutcomes relationship. Am J Sports Med 2018;46:1284-1293. https://doi.org/10.1177/0363546517749219

12. Flores SE, Borak KR, Zhang AL. Hip arthroscopic surgery for femoroacetabular impingement: A prospective analysis of the relationship between surgeon experience and patient outcomes. Orthop J Sports Med 2018;6: 2325967118755048.

13. Konan S, Rhee S-J, Haddad FS. Hip arthroscopy: Analysis of a single surgeon's learning experience. J Bone Joint Surg Am 2011;93:52-56 (suppl 2). https://doi.org/10.2106/JBJS.J.01587

14. Souza BGSE, Dani WS, Honda EK, et al. Do complications in hip arthroscopy change with experience? Arthroscopy 2010;26:10531057.

https://doi.org/10.1016/j.arthro.2009.12.021 
15. Sutter R, Dietrich TJ, Zingg PO et al. How useful is the alpha angle for discriminating between symptomatic patients with cam-type femoroacetabular impingement and asymptomatic volunteers? Radiology 2012;264:514-521.

https://doi.org/10.1148/radiol.12112479

16. Jamali AA, Mladenov K, Meyer DC, et al. Anteroposterior pelvic radiographs to assess acetabular retroversion: High validity of the "cross-over-sign". J Orthop Res 2007;25:758-765. https://doi.org/10.1002/jor.20380

17. Kutty $S$, Schneider $P$, Faris $P$, et al. Reliability and predictability of the centre-edge angle in the assessment of pincer femoroacetabular impingement. Int Orthop 2012;36:505-510. https://doi.org/10.1007/s00264-011-1302-y

18. Kovalenko B, Bremjit P, Fernando N. Classifications in brief: Tönnis classification of hip osteoarthritis. Clin Orthop Relat Res 2018;476:1680-1684. https://doi.org/10.1097/01.blo.0000534679.75870.5f

19. Philippon MJ, Briggs KK, Yen YM, et al. Outcomes following hip arthroscopy for femoroacetabular impingement with associated chondrolabral dysfunction: minimum two-year follow-up. J Bone Joint Surg Br. 2009 Jan;91(1):16-23. https://doi.org/10.1302/0301-620X.91B1.21329

20. Polat G, Çelik D, Çil $H$ et al. Evidence for reliability, validity and responsiveness of Turkish version of Hip Outcome Score. Acta Orthop Traumatol Turc. 2017 Jul;51(4):319-32 https://doi.org/10.1016/j.aott.2017.05.001

21. Perets I, Hartigan DE, Walsh JP et al. Excision of labral amorphous calcification as a part of hip arthroscopy-clinical outcomes in a matched-controlled study. Arthroscopy. 2018 Apr;34(4):12271233 https://doi.org/10.1016/j.arthro.2017.10.025

22. Menge TJ, Briggs KK, Dornan GJ et al. Survivorship and outcomes 10 years following hip arthroscopy for femoroacetabular impingement: labral debridement compared with labral repair.J Bone Joint Surg Am. 2017 Jun 21;99(12):997-1004 https://doi.org/10.2106/JBJS.16.01060
23. Kunze KN, Bart JA, Ahmad M et al. Large heterogeneity among minimal clinically important differences for hip arthroscopy outcomes: a systematic review of reporting trends and quantification methods. Arthroscopy. 2020 Nov 10:S0749-8063(20)30939-7

24. Copay AG, Subach BR, Glassman SD et al. Understanding the minimum clinically important difference: a review of concepts and methods. Spine J 2007;7:541-546. https://doi.org/10.1016/j.spinee.2007.01.008

25. Beck EC, Nwachuckwu BU, Jan K et al. Hip arthroscopy for femoroacetabular impingement syndrome in adolescents provides clinically significant outcome benefit at minimum five year follow-up. Arthroscopy. 2020 Dec 23:S0749-8063(20)31246-9. doi: 10.1016/j.arthro.2020.12.188

26. Lee JW, Hwang DS, Kang C et al. Arthroscopic repair of acetabular labral tears associated with femoroacetabular impingement: 7-10 years of long-term follow-up results. .Clin Orthop Surg. 2019 Mar;11(1):28-35. doi: 10.4055/cios.2019.11.1.28

27. Go CC, Kyin C, Maldonado DR et al. Surgeon experience in hip arthroscopy affects surgical time, complication rate, and reoperation rate: a systematic review on the learning curve. Arthroscopy. 2020 Dec;36(12):3092-3105 https://doi.org/10.1016/j.arthro.2020.06.033

28. Levy DM, Kuhns BD, Chahal J et al. Hip arthroscopy outcomes with respect to patient acceptable symptomatic state and minimal clinically important difference. Arthroscopy 2016;32:18771886 https://doi.org/10.1016/j.arthro.2016.05.014

29. Bessa FS, Williams BT, Polce EM et al. No differences in hip joint space measurements between weightbearing or supine anteroposterior pelvic radiographs. Arthroscopy. 2020 Nov;36(11):28432848 https://doi.org/10.1016/j.arthro.2020.07.009 